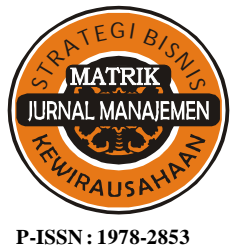

E-ISSN : 2302-8890

\section{MATRIK: JURNAL MANAJEMEN, STRATEGI BISNIS DAN KEWIRAUSAHAAN}

Homepage: https://ojs.unud.ac.id/index.php/jmbk/index

Vol. 14 No. 1, Februari 2020, 45 - 55

\title{
Evaluasi Lingkungan dan Situasi Ritel Modern dengan Importance- Performance Analysis untuk Meningkatkan Niat Pembelian Ulang
}

\author{
Hanum Rachmawati Nur ${ }^{1)}$, Megawati Simanjuntak ${ }^{2}$, Bagus Sartono ${ }^{3)}$ \\ ${ }^{1}$ Sekolah Bisnis, Institut Pertanian Bogor (IPB) \\ ${ }^{2}$ Departemen Ilmu Keluarga dan Konsumen, Fakultas Ekologi Manusia, Institut Pertanian Bogor (IPB) \\ ${ }^{3}$ Departemen Statistika, Fakultas Matematika dan Ilmu Pengetahuan Alam, Institut Pertanian Bogor (IPB) \\ email: rachmawati.hanum@gmail.com
}

DOI : https://doi.org/10.24843/MATRIK:JMBK.2020.v14.i01.p05

\begin{abstract}
ABSTRAK
Fokus utama dari penelitian ini adalah menganalisis atribut penting pada ritel modern untuk meningkatkan niat pembelian ulang berdasarkan daya saing dari aspek lingkungan dan situasi ritel modern. Metode Importance-Performance Analysis (IPA), merupakan metode analisis yang digunakan untuk mengetahui tingkat kinerja manajemen ritel modern dalam menciptakan atribut lingkungan dan situasi berbelanja yang nyaman terhadap persepsi pelanggan ritel modern. Penelitian ini melibatkan 244 responden yang berusia minimal 18 tahun dan melakukan pembelian di hypermarket atau supermarket setidaknya 3 kali dalam satu bulan terakhir. Responden penelitian dipilih secara acak dengan menggunakan metode survei secara online. Hasil penelitian menunjukkan bahwa atribut suasana 'kesibukan' pada ritel modern yang tidak mengganggu, kesesuaian harga dengan kualitas produk, sikap pegawai yang lembut, dan jaminan kualitas produk merupakan atribut penting bagi pelanggan yang belum dapat dipenuhi oleh manajemen ritel modern. Atribut lingkungan dan situasi ritel modern tersebut dapat menjadi perhatian utama bagi manajemen ritel modern untuk meningkatkan daya saing sehingga turut meningkatkan niat pembelian ulang pada ritel modern.
\end{abstract}

Kata kunci: Lingkungan dan situasi, Importance-Performance Analysis, niat pembelian ulang, ritel modern.

Environmental Evaluation and Modern Retail Situation with Importance-Performance Analysis to Improve Revenue Purchases

\begin{abstract}
The focus of this study is to analyze importance attributes of the modern ritel to increase repurchase intention based on the competitive factors from environment and situation of the modern ritel. Importance-Performance Analysis (IPA) method is known to analyze actual performance level in order to make a comfortable shopping environment and situation towards the consumer perception. The research were involved 244 respondents aged 18 years and above who made a purchase in hypermarket or supermarket at least three times in the past one month. The respondents were randomly selected by online survey. The results of this study shows that 'rushing' situation causes of unfavorable activities, price fairness, the gentleness of employees, and quality assurance are important attributes for the customers which have not fulfilled by the modern ritel management. Those attributes could be the main concern for the modern ritel management to increase the competitive factors so that repurchase intention will increase as well.
\end{abstract}

Keywords: Environment and situation, importance-performance analysis, repurchase intention, modern ritel.

\section{PENDAHULUAN}

Bisnis ritel merupakan bisnis yang penting bagi mata rantai distribusi produk. Selain sebagai perantara dalam distribusi produk, bisnis ritel merupakan rujukan tempat bagi konsumen untuk mendapatkan barang sesuai kebutuhan. Hal ini terkait dengan fungsi lain bisnis ritel yakni sebagai penghimpun berbagai macam produk dari berbagai macam produsen. Oleh karena itu, bisnis ritel sebagai mata rantai terakhir dalam distribusi produk sangat penting bagi produsen, distributor dan konsumen dalam pemenuhan nilai tambah distribusi produk. Bagi produsen dan distributor, bisnis ritel membantu dalam hal pemasaran produk, sementara bagi konsumen, bisnis ritel membantu dalam hal pemenuhan kebutuhan rumah tangganya. Berdasarkan Peraturan Presiden Republik Indonesia No. 112 tahun 2007 tentang Penataan dan Pembinaan Pasar Tradisional Pusat Perbelanjaan dan Toko Modern, jenis ritel modern terbagi menjadi dua kelompok 
besar yakni pasar tradisional dan toko modern (Kementerian Sekretariat Negara Republik Indonesia, 2007). Kedua jenis ritel tersebut memiliki ketentuan zonasi sesuai kondisi sosial ekonomi lingkungan sekitarnya, luas lantai, dan sistem penjualan yang berbeda. Namun demikian, baik pasar tradisional dan toko modern, memiliki definisi yang sama yakni sebagai area tempat jual beli barang dengan dengan jumlah penjual lebih dari satu.

Bisnis ritel saat ini sedang mengalami ancaman, terutama bisnis ritel modern. Hingga tahun 2016, pasar tradisional masih mendominasi nilai penjualan kategori ritel di Indonesia sebesar 82,88 persen, sisanya yakni sebesar 17,12 persen adalah proporsi nilai penjualan kategori ritel untuk jenis ritel moden. Bahkan, jumlah gerai ritel modern di Indonesia semakin menurun sejak tahun 2013 terutama pada jenis ritel modern hypermarket dan supermarket (United States Departement of Agriculture, 2017). Penurunan ini diyakini akibat pergeseran minat belanja secara offline menjadi secara online. Berdasarkan survei yang dilakukan oleh Asosiasi Pengguna Jasa Internet Indonesia, diketahui bahwa sebanyak 62 persen pengguna internet di Indonesia lebih sering mengunjungi online shop dibandingkan konten komersil lainnya (Asosiasi Pengguna Jasa Internet Indonesia, 2016). Ancaman tersebut turut didukung oleh penetrasi internet di Indonesia yang hingga tahun 2017, telah mencapai 54,68 persen dari keseluruhan penduduk Indonesia (Asosiasi Pengguna Jasa Internet Indonesia, 2017). Alternatif berbelanja online yang semakin marak akan mengubah gaya hidup dan perilaku pembelian pelanggan (Farki et al., 2016). Artinya minat belanja penduduk Indonesia pada ritel modern, terutama hypermarket dan supermarket, dimasa depan akan semakin menurun.

Demi mempertahankan eksistensi bisnis ritel modern di Indonesia, pelaku bisnis ritel modern perlu memiliki strategi yang tepat untuk tetap mempertahankan pelanggannya. Salah satu cara yang dapat dilakukan adalah menumbuhkan niat pembelian ulang pada bisnis ritel modern karena pelanggan cenderung memiliki keinginan untuk membeli produk atau brand lebih dari satu kali (Pham et al., 2018). Niat pembelian ulang menurut Hellier et al. (2003) adalah keputusan suatu individu untuk membeli produk atau layanan yang sama dari perusahaan yang sama dengan mempertimbangkan pengalaman situasi dan keadaan berbelanja sebelumnya. Perbedaan keadaan aktual dan keadaan yang diekspektasikan oleh pelanggan merupakan faktor yang dapat menentukan pembelian ulang pada suatu merek atau brand tertentu (Ismoyo et al., 2018).

Niat pembelian ulang diketahui memiliki hubungan terhadap emosi karena emosi yang dirasakan berpeluang bagi pelanggan untuk melakukan perpindahan merek (Prastyaningsih et al., 2014). Respon emosi pelanggan disebabkan oleh evaluasi kognitif berdasarkan pengalaman berbelanja sebelumnya (Dawson et al., 1990). Respon emosi dapat secara langsung ditimbulkan akibat lingkungan berbelanja, dengan demikian pengusaha ritel berusaha untuk membuat tempat berbelanja senyaman mungkin untuk meminimalkan efek negatif dari kondisi yang tidak diinginkan oleh pelanggan (Machleit dan Eroglu, 2000). Berdasarkan hal tersebut, lingkungan menjadi aspek penting yang perlu diperhatikan karena lingkungan yang baik memicu emosi positif selama berbelanja (Rianto $e t$ al., 2018).

Lingkungan dan situasi yang ditimbulkan dari suasana ritel dapat menarik perhatian pelanggan bahkan mempengaruhi keputusan pembelian pelanggan. Hal ini disebabkan oleh persepsi atribut pada toko yang dibentuk dari pengalaman langsung selama berbelanja (Ghosh et al., 2010). Pelanggan melakukan evaluasi dalam berbelanja berdasarkan atribut pada toko dan preferensi secara individu (Tripathi dan Sinha, 2008). Menurut Turley dan Milliman (2000) lingkungan fisik yang membentuk pengalaman berbelanja akan mempengaruhi respon pelanggan yang positif atau negatif. Pelanggan yang merespon positif atas pengalaman berbelanja yang dirasakan, cenderung akan berbelanja lebih lama dan akan melakukan pembelian berulang di masa depan (Yuniarinto et al., 2017).

Atribut yang diketahui berpengaruh pada emosi dan niat pembelian ulang adalah persepsi kepadatan. Menurut Gogoi (2017) persepsi kepadatan terjadi karena persepsi keterbatasan ruang dan dapat dikaitkan akibat lingkungan dan persepsi individu. Pelanggan yang berbeda dapat merasakan kepadatan yang berbeda pada suatu lingkungan toko yang sama, hal tersebut bergantung pada karakteristik setiap individu (Machleit dan Eroglu, 2000). Secara umum, persepsi kepadatan terbagi atas dua dimensi yakni sosial dan spasial. Kepadatan sosial erat kaitannya dengan kesesakan akibat jumlah kepadatan manusia, sedangkan kepadatan spasial berkaitan dengan keterbatasan ruang gerak akibat 
kepadatan benda fisik disekitar (Eroglu dan Harrell, 1986).

Citra toko adalah sesuatu yang bersifat simbolis, yang merupakan sebuah ekspresi berdasarkan visualisasi pelanggan saat berbelanja (Saraswat $e t$ $a l ., 2010)$. Citra toko terbagi atas dua dimensi atribut, yakni atribut nyata dan tidak nyata. Aspek nyata dari citra toko direpresentasikan atas fungsi fisik toko, sedangkan aspek tidak nyata dari citra toko direpresentasikan atas perasaan yang timbul dari dalam diri pelanggan atas pengalaman berbelanjanya (Mamalis et al., 2005; Saraswat et al., 2010). Citra toko akan membangun persepsi pelanggan yang ditandai dengan pembelian ulang di masa depan dan tingkat kepuasan pelanggan (Hosseini et al., 2014). Kajian lain juga menunjukkan preferensi (Pebriani et al., 2018), serta harga dan citra mempengaruhi juga pembelian ulang (Shabrina et al., 2018). Menurut Kunkel dan Berry (2006) citra toko akan terbentuk setelah membandingkan ekpektasi dengan pengalaman berbelanja yang dirasakan, sehingga perbandingan yang tersebut menentukan niat pembelian kembali dimasa depan.

Pengaruh lingkungan dan situasi berbelanja menimbulkan motif berbelanja yang berbeda. Motif belanja terdiri atas dua dimensi, yakni hedonis dan utilitarian. Motif belanja hedonis mencerminkan hiburan, emosi, dan kebebasan dalam berbelanja sedangkan motif belanja utilitarian lebih mencerminkan pada penilaian kognitif, ketercapaian tujuan dalam berbelanja, dan bersifat non-emosional (Babin et al., 1994). Menurut Yüksel (2007), apabila tujuan berbelanja masing-masing motif tercapai maka akan terbentuk emosi positif sehingga berbelanja menjadi menyenangkan. Pengalaman berbelanja yang positif diharapkan dapat menimbulkan niat pembelian ulang pada ritel modern.

Penelitian hubungan antara atribut ritel modern terhadap emosi dan niat pembelian ulang telah umum dilakukan menggunakan metode Structural Equation Model (SEM), namun hal tersebut belum cukup untuk menegaskan sisi keunggulan kompetitif dan atribut yang perlu menjadi perhatian khusus untuk meningkatkan keunggulan tersebut. Metode Importance-Performance Analysis (IPA) didasari atas model multi-atribut, yang umumnya digunakan untuk melakukan analisis kinerja suatu industri (Martilla dan James, 1977). Metode IPA umumnya digunakan oleh pihak manajemen untuk membantu dalam identifikasi atribut yang memiliki kinerja efektif dan atribut yang membutuhkan perbaikan (Shieh dan $\mathrm{Wu}, 2009)$. Metode IPA merupakan teknik untuk mengevaluasi strategi yang ada, mengidentifikasi prioritas peningkatan untuk atribut layanan, dan mengembangkan strategi pemasaran baru yang efektif (Hansen dan Bush, 1999).

Sejumlah penelitian mengenai analisis kinerja menggunakan metode IPA telah dilakukan, diantaranya analisis multi-atribut pada industri pariwisata (Deng \& Pierskalla, 2018), pelayanan dan kualitas pada hotel (Blešić et al., 2014), dan pelayanan makanan pada suatu rumah makan (Obonyo et al., 2012). Berdasarkan hal tersebut, perumusan strategi pemasaran menggunakan metode IPA untuk meningkatkan niat pembelian pada ritel modern diharapkan dapat mejadi pengembangan strategi pemasaran yang baru bagi manajemen ritel modern. Melalui identifikasi kebutuhan, keinginan, dan harapan pelanggan, pelaku bisnis ritel modern dapat menentukan strategi yang lebih baik, yang telah disesuaikan dengan kebutuhan pelanggan. Hal ini tentu akan berdampak pada peningkatan keunggulan kompetitif bisnis ritel modern terhadap pesaing bisnis ritel lainnya.

Penelitian ini bertujuan untuk mengidentifikasi atribut-atribut yang perlu menjadi perbaikan pada ritel modern, yang berkaitan dengan lingkungan dan situasi berbelanja menggunakan metode IPA. Jenis ritel modern yang menjadi fokus pada penelitian adalah hypermarket dan supermarket, dengan atribut yang menjadi penilaian adalah persepsi kepadatan, citra toko, dan motif belanja.

\section{METODE PENELITIAN}

Pendekatan penelitian yang digunakan adalah deskriptif kuantitatif menggunakan metode survei online kepada pelanggan ritel modern. Populasi sampel adalah pelanggan ritel modern tipe hypermarket dan supermarket. Metode pengambilan sampel penelitian yang digunakan adalah purposive sampling, dengan kriteria responden yakni berusia minimal 18 tahun dan pernah melakukan pembelian di hypermarket atau supermarket minimal tiga kali dalam satu bulan terakhir.

Jumlah indikator penelitian yang menyusun model penelitian adalah 44 indikator. Menurut Hair et al. (2006) estimasi jumlah sampel yang dibutuhkan pada setiap parameter adalah lima hingga sepuluh obervasi. Berdasarkan hal tersebut, maka batasan jumlah sampel minimal adalah 220 individu dan 
maksimal adalah 440 individu. Jumlah responden yang mengisi survei adalah 501 individu sedangkan jumlah responden yang memenuhi kriteria adalah 244 individu, sehingga jumlah sampel yang digunakan pada penelitian adalah 244 individu.

Variabel yang digunakan pada penelitian diantaranya adalah persepsi kepadatan, citra toko, dan motif belanja. Persepsi kepadatan dibangun atas dua dimensi yakni sosial dan spasial (Bakker, 2010).
Citra toko dibangun atas lima dimensi yakni pelayanan pegawai, kualitas produk, atmosfer, kenyamanan, dan harga (Chowdhury et al., 1998). Motif belanja dibangun atas dua dimensi yakni hedonis dan utilitarian (Rintamäki et al., 2006). Skala pengukuran yang digunakan adalah skala likert lima tingkat yaitu (1) sangat tidak setuju, (2) tidak setuju, (3) cukup setuju, (4) setuju, (5) sangat setuju.

Tabel 1. Atribut Penilaian Pada Ritel Modern

\begin{tabular}{|c|c|c|c|}
\hline Variabel & Dimensi & & Indikator \\
\hline \multirow{6}{*}{$\begin{array}{l}\text { Persepsi Kepadatan } \\
\text { (Bakker, 2010) }\end{array}$} & \multirow{3}{*}{ Sosial } & SOS1 & Kerumunan \\
\hline & & SOS2 & Kesibukan \\
\hline & & SOS3 & Suasana lapang \\
\hline & \multirow{3}{*}{ Spasial } & SPA1 & Posisi barang atau produk \\
\hline & & SPA2 & Luas ruangan \\
\hline & & SPA3 & Kecukupan ruang \\
\hline \multirow{20}{*}{$\begin{array}{c}\text { Citra Toko } \\
\text { (Chowdhury et al., } \\
\text { 1998) }\end{array}$} & \multirow{4}{*}{$\begin{array}{l}\text { Pelayanan } \\
\text { Pegawai }\end{array}$} & EMS1 & Keramahan \\
\hline & & EMS2 & Kejujuran \\
\hline & & EMS3 & Sikap lemah lembut \\
\hline & & EMS4 & Pelayanan secara keseluruhan \\
\hline & \multirow{6}{*}{ Kualitas Produk } & KUP1 & Kualitas produk \\
\hline & & KUP2 & Kesegaran produk \\
\hline & & KUP3 & Keterjaminan kualitas \\
\hline & & KUP4 & Kesesuaian kualitas dengan ekspektasi \\
\hline & & KUP5 & Variasi produk \\
\hline & & KUP6 & Produk local \\
\hline & \multirow{3}{*}{ Atmosfer } & ATO1 & Tempat baik secara umum \\
\hline & & ATO2 & Tampilan bersih \\
\hline & & ATO3 & Tampilan gedung tidak usang \\
\hline & \multirow{4}{*}{ Kenyamanan } & KNY1 & Keterjangkauan lokasi \\
\hline & & KNY2 & Kerapian \\
\hline & & KNY3 & Kemudahan petunjuk informasi \\
\hline & & KNY4 & Kemudahan petunjuk harga \\
\hline & \multirow{3}{*}{ Harga } & HRG1 & Harga murah secara keseluruhan \\
\hline & & HRG2 & Kesesuaian harga dengan kualitas \\
\hline & & HRG3 & Kemudahan menemukan produk murah \\
\hline \multirow{12}{*}{$\begin{array}{c}\text { Motif Belanja } \\
\text { (Rintamäki et al., } \\
\text { 2006) }\end{array}$} & \multirow{6}{*}{ Hedonik } & HED1 & Gemar aktivitas belanja secara umum \\
\hline & & HED2 & Belanja untuk bersenang-senang \\
\hline & & HED3 & Belanja untuk mengisi waktu luang \\
\hline & & HED4 & Tertarik untuk berkeliling \\
\hline & & HED5 & Tertarik untuk mencoba produk \\
\hline & & HED6 & Ingin berbelanja lebih banyak. \\
\hline & \multirow{6}{*}{ Utilitarian } & UTI1 & Penghematan uang \\
\hline & & UTI2 & Tertarik dengan produk murah \\
\hline & & UTI3 & Gemar membandingkan harga \\
\hline & & UTI4 & Efisien dalam pencarian produk \\
\hline & & UTI5 & Tidak menyukai antrian \\
\hline & & UTI6 & Penghematan waktu \\
\hline
\end{tabular}

sumber : Data diolah 
Data yang dikumpulkan berupa data primer dari responden berupa informasi yang meliputi variabel penelitian. Instrumen yang digunakan dalam penelitian ini, yaitu kuesioner online dengan bantuan Google Docs. Kuesioner terbagi atas tiga bagian utama yakni screening, profiling, dan pertanyaan utama terkait indikator penelitian. Kuesioner online disebar dalam bentuk link Google Docs melalui berbagai aplikasi sosial media. Jenis pertanyaan dalam penelitian menggunakan pertanyaan secara tertutup.

Uji validitas dan reliabilitas instrumen digunakan untuk memastikan bahwa alat ukur telah mencerminkan sesuai dengan keadaan dan bersifat konsisten. Validitas digambarkan dengan koefisien korelasi pearson, sementara reliabilitas digambarkan dengan nilai Alpha Cronbach's. Teknik analisis data yang digunakan adalah metode ImportancePerformance Analysis (IPA) yang menunjukkan hubungan antara tingkat kepentingan dan tingkat kinerja. Tingkat kepentingan pada sumbu Y diukur berdasarkan penilaian loading factor dari perhitungan metode Structured Equation Model (SEM), sedangkan tingkat kinerja pada sumbu $\mathrm{X}$ diukur berdasarkan nilai rata-rata yang diberikan setiap responden pada setiap indikator. Garis pembagi tingkat kepentingan dihitung berdasarkan nilai rata-rata loading factor, sedangkan garis pembagi tingkat kinerja dihitung berdasarkan nilai rata-rata penilaian responden pada setiap indikator. Setiap atribut atau indikator tingkat kepentingan dan tingkat kinerja dijabarkan pada diagram seperti pada Gambar 1.

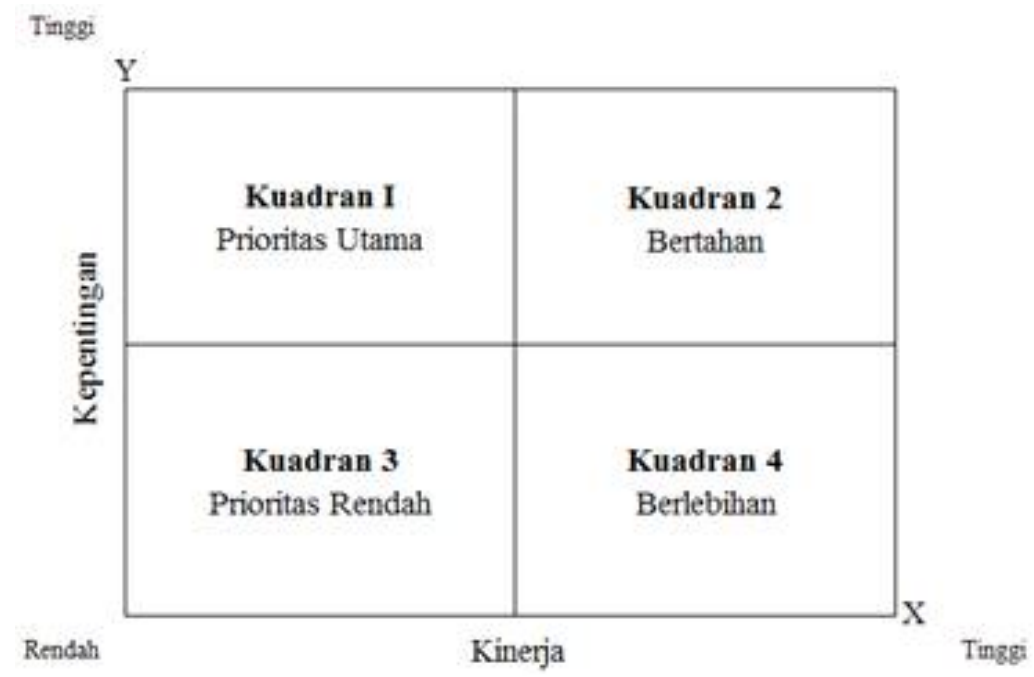

Sumber: Rangkuti, 2003

Gambar 1. Diagram Importance-Performance Analysis

\section{HASIL DAN PEMBAHASAN}

Karakteristik responden pelanggan ritel modern digambarkan melalui aspek demografi diantaranya jenis kelamin, usia, domisili, pendidikan terakhir, dan pekerjaan saat ini. Karakteristik responden bertujuan untuk membantu memahami keragaman jawaban dari responden. Jenis kelamin responden yang merupakan pelanggan ritel modern sebagian besar adalah Perempuan yakni sebesar 60,6 persen sedangkan laki-laki memiliki persentase sebesar 39,3 persen. Karakteristik usia responden didominasi kisaran usia 25-34 tahun dengan persentase sebesar 43,4 persen, sedangkan responden yang paling sedikit adalah kisaran usia 55-64 tahun yakni sebesar 2 persen. Tingkat pendidikan responden yang merupakan pelanggan ritel modern didominasi oleh tingkat pendidikan sarjana yakni 70,1 persen.
Responden yang merupakan pelanggan ritel modern didominasi oleh pegawai swasta yakni 46,7 persen.

Rata-rata persepsi pada tiap indikator merupakan dasar untuk menentukan tingkat baik atau tidaknya suatu kinerja pada ritel modern. Hal ini dilakukan dengan membandingkan nilai persepsi pelanggan dalam suatu indikator tertentu terhadap nilai rata-rata persepsi pelanggan seluruh indikator. Pada hal ini, nilai rata-rata persepsi pelanggan seluruh indikator adalah sebesar 3,69. Rata-rata loading factor merupakan dasar untuk menentukan tingkat kepentingkan suatu indikator. Hal ini dilakukan dengan membandingkan nilai loading factor suatu indikator terhadap nilai rata-rata loading factor seluruh indikator. Nilai rata-rata loading factor seluruh indikator adalah 0,79 . Hasil perhitungan dan penilaian secara keseluruhan ditunjukkan pada Tabel 2. 
Tabel 2. Penilaian Kepentingan dan Kinerja Ritel Modern

\begin{tabular}{|c|c|c|c|c|c|}
\hline Variabel & Dimensi & & Indikator & Importance & Performance \\
\hline \multirow{6}{*}{$\begin{array}{c}\text { Persepsi } \\
\text { Kepadatan }\end{array}$} & \multirow{3}{*}{ Sosial } & SOS1 & Kerumunan & 0,74 & 3,07 \\
\hline & & SOS2 & Kesibukan & 0,90 & 3,32 \\
\hline & & SOS3 & Suasana lapang & 0,65 & 2,86 \\
\hline & \multirow{3}{*}{ Spasial } & SPA1 & Posisi barang atau produk & 0,92 & 4,18 \\
\hline & & SPA2 & Luas ruangan & 0,72 & 4,16 \\
\hline & & SPA3 & Kecukupan ruang & 0,90 & 4,21 \\
\hline \multirow{20}{*}{ Citra Toko } & \multirow{4}{*}{$\begin{array}{c}\text { Pelayanan } \\
\text { Pegawai }\end{array}$} & EMS1 & Keramahan & 0,89 & 3,91 \\
\hline & & EMS2 & Kejujuran & 0,81 & 3,88 \\
\hline & & EMS3 & Sikap lemah lembut & 0,84 & 3,76 \\
\hline & & EMS4 & Pelayanan secara keseluruhan & 0,91 & 3,88 \\
\hline & \multirow{6}{*}{ Kualitas Produk } & KUP1 & Kualitas produk & 0,76 & 3,94 \\
\hline & & KUP2 & Kesegaran produk & 0,66 & 3,82 \\
\hline & & KUP3 & Keterjaminan kualitas & 0,84 & 3,89 \\
\hline & & KUP4 & $\begin{array}{l}\text { Kesesuaian kualitas dengan } \\
\text { ekspektasi }\end{array}$ & 0,86 & 3,94 \\
\hline & & KUP5 & Variasi produk & 0,69 & 4,10 \\
\hline & & KUP6 & Produk lokal & 0,74 & 4,20 \\
\hline & \multirow{3}{*}{ Atmosfer } & ATO1 & Tempat baik secara umum & 0,73 & 3,69 \\
\hline & & ATO2 & Tampilan bersih & 0,82 & 4,03 \\
\hline & & ATO3 & Tampilan gedung tidak usang & 1,00 & 3,98 \\
\hline & \multirow{4}{*}{ Kenyamanan } & KNY1 & Keterjangkauan lokasi & 0,70 & 4,30 \\
\hline & & KNY2 & Kerapian & 0,83 & 4,09 \\
\hline & & KNY3 & Kemudahan petunjuk informasi & 0,73 & 3,84 \\
\hline & & KNY4 & Kemudahan petunjuk harga & 0,80 & 3,90 \\
\hline & \multirow{3}{*}{ Harga } & HRG1 & Harga murah secara keseluruhan & 0,55 & 3,52 \\
\hline & & HRG2 & Kesesuaian harga dengan kualitas & 0,87 & 3,90 \\
\hline & & HRG3 & $\begin{array}{l}\text { Kemudahan menemukan produk } \\
\text { murah }\end{array}$ & 0,65 & 3,68 \\
\hline
\end{tabular}

Tabel 2. Penilaian Kepentingan Dan Kinerja Ritel Modern (lanjutan)

\begin{tabular}{|c|c|c|c|c|c|}
\hline Variabel & Dimensi & & Indikator & Importance & Performance \\
\hline \multirow{12}{*}{ Motif Belanja } & \multirow{6}{*}{ Hedonik } & HED1 & Gemar aktivitas belanja secara umum & 0,90 & 3,34 \\
\hline & & HED2 & Belanja untuk bersenang-senang & 0,86 & 3,13 \\
\hline & & HED3 & Belanja untuk mengisi waktu luang & 0,80 & 3,20 \\
\hline & & HED4 & Tertarik untuk berkeliling & 0,95 & 3,68 \\
\hline & & HED5 & Tertarik untuk mencoba produk & 0,85 & 3,36 \\
\hline & & HED6 & Ingin berbelanja lebih banyak, & 0,74 & 3,28 \\
\hline & \multirow{6}{*}{ Utilitarian } & UTI1 & Penghematan uang & 0,72 & 3,24 \\
\hline & & UTI2 & Tertarik dengan produk murah & 0,68 & 3,34 \\
\hline & & UTI3 & Gemar membandingkan harga & 0,72 & 3,25 \\
\hline & & UTI4 & Efisien dalam pencarian produk & 0,86 & 3,86 \\
\hline & & UTI5 & Tidak menyukai antrian & 0,74 & 2,97 \\
\hline & & UTI6 & Penghematan waktu & 0,67 & 3,43 \\
\hline Nilai rata-rata & & & & 0,79 & 3,69 \\
\hline Nilai tertinggi & & & & 0,55 & 2,86 \\
\hline Nilai terendah & & & & 1,00 & 4,30 \\
\hline
\end{tabular}

Tingkat kepentingan suatu atribut memiliki bobot yang berbeda. Pembobotan kepentingan setiap atribut dinilai berdasarkan nilai loading factor. Tingkat kepentingan tersebut menggambarkan harapan atas atribut pelayanan pada ritel modern. Berdasarkan hasil penelitian, nilai loading factor tertinggi adalah 1,00 yakni ditunjukkan pada atribut ATO3. Artinya, atribut tampilan gedung yang tidak 
usang merupakan atribut yang diharapkan oleh pelanggan pada suatu ritel modern. Nilai loading factor terendah ditunjukkan pada atribut HRG1 yakni harga yang tergolong murah, sebesar 0,55. Artinya, harga produk tergolong murah bukan merupakan atribut yang diharapkan oleh pelanggan ritel modern.

Tingkat kinerja ritel modern dinilai berdasarkan nilai rata-rata yang diberikan oleh setiap responden. Tingkat kinerja tertinggi adalah indikator KNY1 yakni keterjangkauan lokasi, dengan nilai rata-rata sebesar 4,30. Artinya, keterjangkauan lokasi ritel modern dengan pelanggan adalah salah satu atribut yang sudah dinilai baik oleh pelanggan. Nilai ratarata terendah adalah indikator SOS3 yakni suasana ritel modern yang lapang, dengan nilai rata-rata sebesar 2,86. Artinya, pelanggan ritel modern belum merasa bahwa suasana ritel modern yang dirasakan masih dipenuhi oleh pengunjung lain.
Strategi pengembangan ritel modern disusun berdasarkan prioritas perbaikan atribut menggunakan metode Importance-Performance Analysis (IPA). Metode tersebut mampu menggambarkan atribut penting khususnya untuk pengembangan strategi pemasaran (Martilla dan James, 1977). Selain itu, grafik pada metode tersebut, manajemen dapat menentukan atribut terpenting yang perlu ditingkatkan berdasarkan pengukuran persepsi pelanggan terhadap atributatribut pelayanan atau jasa (Wong et al., 2011). Penggunaan metode IPA tidak hanya menganalisis kinerja pada suatu atribut saja, tetapi juga pentingnya atribut tersebut sebagai faktor penentu dalam kepuasan pelanggan (Silva dan Fernandes, 2011). Gambar 2 menunjukkan analisis kinerja berdasarkan persepsi pelanggan ritel modern.

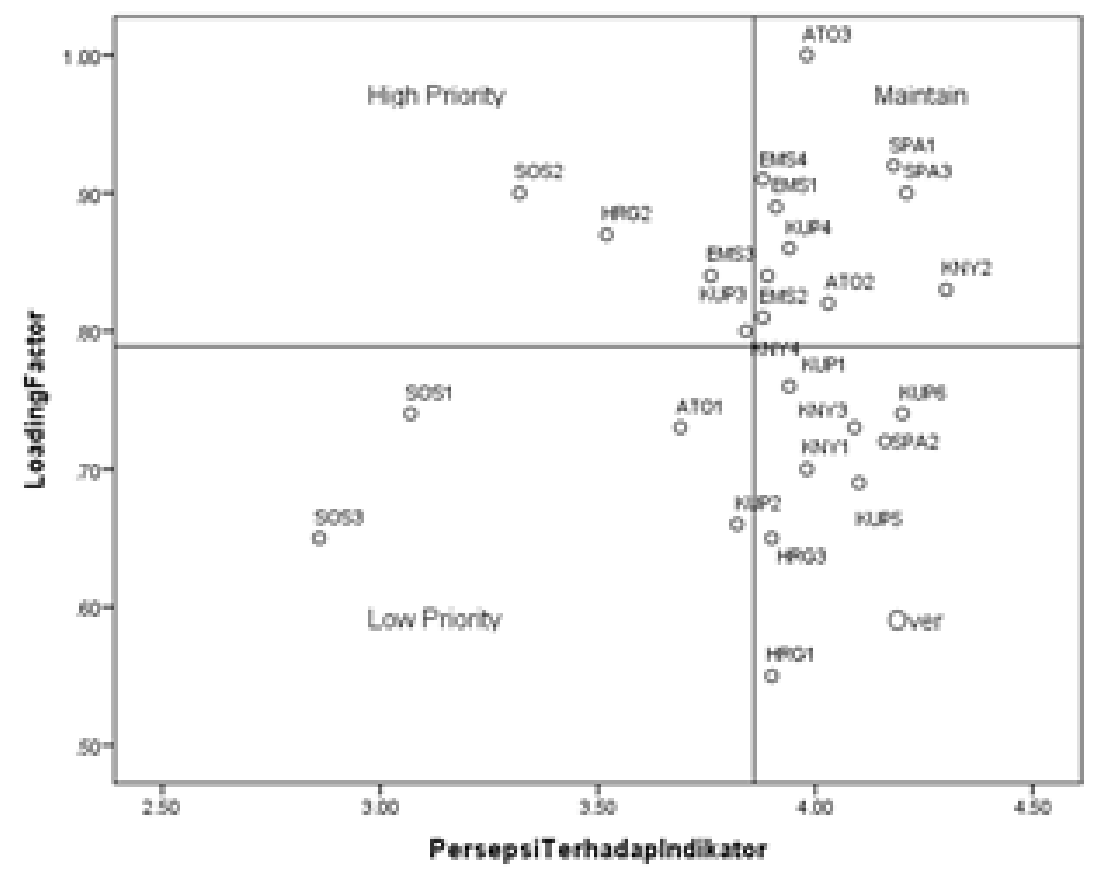

\section{Gambar 2. Analisis Kinerja Berdasarkan Persepsi Pelanggan Ritel Modern}

Kuadran pertama adalah tingkat prioritas tinggi namun persepsi terhadap indikator rendah (high priority). Pada kuadran ini memuat atribut-atribut yang dianggap penting oleh pelanggan, namun belum sesuai dengan harapan pelanggan (Wong et al., 2011). Indikator yang masuk kedalam kuadran pertama merupakan atribut yang harus ditingkatkan. Berdasarkan Gambar 2, kesibukan (SOS2), kesesuaian harga dengan kualitas (HRG2), sikap lemah lembut pegawai (EMS3), dan keterjaminan kualitas (KUP3) adalah indikator yang masuk kedalam kuadran pertama. Artinya, untuk meningkatkan niat pembelian ulang pada suatu ritel modern, pihak manajemen perlu untuk meningkatkan atribut-atribut tersebut.

Kuadran kedua adalah tingkat prioritas tinggi dan persepsi terhadap indikator tinggi (maintain). Pada kuadran ini memuat atribut yang perlu dipertahankan karena telah memenuhi harapan pelanggan (Wong et al., 2011). Berdasarkan Gambar 2, atribut yang termasuk pada kuadran kedua adalah tampilan gedung tidak usang (ATO3), 
posisi barang atau produk (SPA1), pelayanan secara keseluruhan (EMS4), keramahan (EMS1), kesesuaian kualitas dengan ekspektasi (KUP4), kejujuran (EMS2), tampilan bersih (ATO2), kerapian (KNY2). Artinya, artibut-atribut tersebut merupakan kekuatan yang perlu dipertahankan oleh manajemen ritel modern. Apabila kekuatan tersebut gagal dipertahankan, maka atribut tersebut menjadi prioritas utama yang perlu dikembangkan.

Kuadran ketiga adalah tingkat prioritas rendah dan persepsi terhadap indikator rendah (low priority). Kuadran ini merupakan prioritas rendah karena memuat atribut-atribut yang dianggap kurang penting oleh pelanggan (Wong et al., 2011). Berdasarkan Gambar 2, atribut yang termasuk pada kuadran ketiga adalah kerumunan (SOS1), suasana lapang (SOS3), tempat baik secara umum (ATO1), dan kesegaran produk (KUP2). Artinya, apabila atribut tersebut gagal dipertahankan maka pelanggan akan tetap memiliki minat pembelian ulang pada ritel modern sehingga hal ini tidak akan menjadi ancaman bagi manajemen ritel modern.

Kuadran keempat adalah tingkat prioritas rendah dan persepsi terhadap indikator tinggi (over). Pada kuadran ini memuat kinerja atribut yang berlebihan sehingga alokasi sumber daya sebaiknya digunakan untuk meningkatkan perbaikan pada atribut kuadran pertama (Wong et al., 2011). Berdasarkan Gambar 2, atribut yang termasuk pada kuadran keempat adalah kualitas produk secara umum (KUP1), variasi produk (KUP5), kemudahan pencarian informasi produk (KNY3), ruangan yang luas (SPA2), kemudahan dijangkau (KNY1), ketersediaan produk dalam negeri (KUP6), harga murah secara keseluruhan (HRG1), dan kemudahan menemukan produk murah (HRG3). Artinya, secara umum atribut tersebut telah memenuhi harapan pelanggan sehingga tidak diperlukan pengembangan berkelanjutan. Alokasi sumber daya untuk pengembangan ritel modern pada aspek tersebut sebaiknya digunakan untuk mengembangkan atribut pada atribut kuadran pertama yakni kesibukan (SOS2), kesesuaian harga dengan kualitas (HRG2), sikap lemah lembut pegawai (EMS3), dan keterjaminan kualitas (KUP3)untuk meningkatkan minat pembelian ulang.

Berdasarkan uraian tersebut, maka atribut pada kuadran pertama (high priority) merupakan atribut prioritas yang penting dalam penambahan daya saing (Ormanoviæ et al., 2017). Hal ini disebabkan karena, pelanggan merasakan bahwa atribut pada kuadran tersebut merupakan atribut yang penting bagi mereka namun terindikasi memiliki tingkat kepuasan yang rendah akibat kinerja manajemen. Atribut yang masuk kedalam kuadran pertama, merupakan atribut utama yang perlu segera dilaksanakan dalam menjalankan strategi pemasaran (Martilla dan James, 1977).

Pada ritel modern, indikator yang masuk ke kuadran pertama secara berurutan yang kesibukan (SOS2), kesesuaian harga dengan kualitas (HRG2), sikap lemah lembut pegawai (EMS3), dan keterjaminan kualitas (KUP3). Penanganan kesibukan agar tidak mengganggu kenyamanan pengunjung dapat ditangani dengan melakukan evaluasi terhadap suatu kepadatan atau antrian dan kegiatan operasional pegawai yang berpotensi mempersulit ruang gerak dari pelanggan. Aspek kesesuaian harga dengan kualitas dapat diatasi dengan melakukan audit kualitas produk terhadap harga sehingga manajemen dapat menilai bahwa kualitas produk yang dijual sesuai dengan penetapan harga pada ritel modern. Sikap pegawai yang lemah lembut dapat ditangani dengan menerapkan Standard Operation Procedure (SOP) terhadap pegawai terkait sikap terhadap pelanggan, selain itu briefing mengenai pentingnya penerapan SOP pada ritel modern perlu dilakukan sebelum memulai aktivitas pelayanan ritel modern. Evaluasi terkait pelaksanaan SOP pada hari tersebut perlu dilakukan untuk mengetahui aspek yang menjadi perhatian untuk perbaikan. Keterjaminan kualitas sangat penting untuk ditangani dengan cara melakukan pengawasan kualitas yang ketat selama produk masih belum terjual, melakukan pengawasan masa kadaluarsa, dan melakukan penilaian potensi bahaya yang dapat mengontaminasi produk.

Beberapa hal tersebut dapat menjadi saran implikasi manajerial bagi perusahaan ritel modern untuk memberikan emosi positif yang berdampak pada niat pembelian ulang ritel modern. Peningkatan keunggulan kompetitif dari hal-hal yang dianggap penting oleh pelanggan diharapkan dapat meningkatkan pembelian ulang pelanggan dimasa depan.

\section{SIMPULAN}

Penggunaan metode Importance-Performance Analysis (IPA) bermanfaat untuk memberikan prioritas perbaikan atribut pada ritel modern berdasarkan tingkat penilaian pelanggan ritel modern. Atribut yang menjadi prioritas utama perbaikan diantaranya adalah kesibukan pada ritel 
modern, kesesuaian harga dengan kualitas, sikap lemah lembut pegawai, dan keterjaminan kualitas. Perbaikan pada aspek-aspek tersebut sangat penting bila ritel modern ingin tetap mempertahankan eksistensi bisnisnya dalam persaingan bisnis ritel saat ini. Beberapa cara yang dapat dilakukan adalah evaluasi kepadatan, antrian, dan kegiatan operasional, penerapan SOP pegawai ritel modern, dan memperketat aspek penjaminan kualitas.

Keterbatasan dalam penelitian ini yaitu hanya menilai berdasarkan aspek lingkungan dan situasi ritel modern. Ritel modern yang diteliti hanya sebatas tipe hypermarket dan supermarket yang berbasiskan produk grosir (groceries) sehingga tidak dapat disimpulkan untuk jenis ritel modern lain seperti mall dan minimarket. Pengumpulan data menggunakan metode purposive sampling pada jenis ritel modern tertentu membuat penelitian tidak dapat digunakan untuk menggambarkan karakteristik populasi ritel modern secara menyeluruh. Penelitian ritel modern berbasiskan produk sandang dan elektronik dapat dilakukan untuk memberikan strategi pemasaran yang lebih spesifik dalam meningkatkan niat pembelian ulang.

\section{REFERENSI}

Asosiasi Pengguna Jasa Internet Indonesia. (2016). Infografis penetrasi dan perilaku pengguna jasa internet Indonesia. Retrieved from https:// apjii.or.id/downfile/downloadsurvei/ infografis_apjii.pdf

Asosiasi Pengguna Jasa Internet Indonesia. (2017). Hasil survey penetrasi dan perilaku pengguna internet Indonesia. Retrieved from https:// apjii.or.id/content/read/39/342/Hasil-SurveiPenetrasi-dan-Perilaku-Pengguna-InternetIndonesia-2017

Babin, B. J., Darden, W. R., \& Griffin, M. (1994). Work and or fun: Measuring hedonic and utilitarian shopping value. Journal of Consumer Research, 20(4), 644-657.

Bakker, S. (2010). Exploring the consequences and antecedents of perceived crowding in the ritel environment. Erasmus University Rotterdam, Rotterdam, Netherland. Retrieved from https://thesis.eur.nl/pub/8528/Bakker, S.R. (302056).docpersen0Apersen0A

Blešiæ, I., Popov-Raljiæ, J., Uraviæ, L., Stankov, U., Đeri, L., Panteliæ, M., \& Armenski, T. (2014). An importance-performance analysis of service quality in spa hotels. Economic
Research-Ekonomska Istrazivanja, 27(1), 483-393. https://doi.org/10.1080/ 1331677X.2014.967537

Chowdhury, J., Reardon, J., \& Srivastava, R. (1998). Alternative modes of measuring store image: An empirical assessment of structured versus unstructured measures. Journal of Marketing Theory and Practice, 6(2), 72-86. https:// doi.org/10.1080/10696679.1998.11501797

Dawson, S., Bloch, P. H., \& Ridgway, N. M. (1990). Shopping motives, emotional states, and ritel outcomes. Journal of Riteling, 66(4), 408427.

Deng, J., \& Pierskalla, C. D. (2018). Linking importance-performance analysis, satisfaction, and loyalty: A study of Savannah, GA. Sustainability, 10(704), 1-17. https://doi.org/ 10.3390/su10030704

Eroglu, S. A., \& Harrell, G. D. (1986). Ritel crowding: Theoretical and strategic implications. Journal of Riteling, 6(4), 346-363. Retrieved from https://psycnet.apa.org/record/198812513-001

Farki, A., Baihaqi, I., \& Wibawa, M. (2016). Pengaruh online customer review dan rating terhadap kepercayaan dan minat beli. Jurnal Teknik ITS, 5(2), 14-19. https://doi.org/ 10.12962/j23373539.v5i2.19671

Ghosh, P., Tripathi, V., \& Kumar, A. (2010). Customer expectations of store attributes: A study of organized ritel outlets in India. Journal of Ritel and Leisure Property, 9(1), 75-87. https://doi.org/10.1057/rlp.2009.27

Gogoi, B. J. (2017). Effect of store design on perceived crowding and impulse buying behavior. International Review of Management and Marketing, 7(2), 180-186. Retrieved from http://dergipark.gov.tr/irmm/ issue/32104/355810

Hair, J. F., Black, W. C., Babin, B. J., \& Anderson, R. E. (2006). Multivariate data analysis (6th ed.). New Jersey, US: Pearson Prentice Hall.

Hansen, E., \& Bush, R. J. (1999). Understanding customer quality requirements: Model and application. Industrial Marketing Management, 28(2), 119-130. https://doi.org/ 10.1016/S0019-8501(98)00007-8

Hellier, P. K., Geursen, G. M., Carr, R. A., \& Rickard, J. A. (2003). Customer repurchase intention: A general structural equation model. 
European Journal of Marketing, 37(11/12), 1762-1800. https://doi.org/10.1108/ 03090560310495456

Hosseini, Z., Jayashree, S., \& Malarvizhi, C. (2014). Store image and its effect on customer perception of ritel stores. Asian Social Science, 10(21), 223-235. https://doi.org/10.5539/ ass.v10n21p223

Ismoyo, N. B., Hadiwidjojo, J., Rahman, F., \& Rahayu, M. (2018). Service quality perception's effect on customer satisfaction and repurchase intention. European Business \& Management, 3(3), 37-46. https://doi.org/10.11648/ j.ebm.20170303.11

Kementerian Sekretariat Negara Republik Indonesia. (2007). Peraturan Presiden Republik Indonesia Nomor 112 Tahun 2007: Penataan dan pembinaan pasar tradisional, pusat perbelanjaan, dan toko modern. Retrieved from http://www.bphn.go.id/data/documents/ 07pr112.pdf

Kunkel, J. H., \& Berry, L. L. (2006). A behavioral conception of ritel image. Journal of Marketing, 32(4), 21-27. https://doi.org/ $10.2307 / 1249333$

Machleit, K. A., \& Eroglu, S. A. (2000). Describing and measuring emotional response to shopping experience. Journal of Business Research, 49(2), 101-111. https://doi.org/10.1016/S01482963(99)00007-7

Mamalis, S., Ness, M., \& Bourlakis, M. (2005). Tangible and intangible factors of store image. In Proceedings of the 5th WSEAS Int. Conf. on DISTANCE LEARNING AND WEB ENGINEERING (pp. 7-12). Corfu, Greece: World Scientific and Engineering Academy and Society (WSEAS). Retrieved from https:// www.researchgate.net/publication/ 234793905_Tangible_and_intangible_factors_ of_store_image

Martilla, J. A., \& James, J. C. (1977). Importanceperformance analysis. Journal of Marketing, 41(1), 77-79. https://doi.org/10.2307/1250495

Obonyo, G. O., Ayieko, M. A., \& Kambona, O. O. (2012). An importance-performance analysis of food service attributes in gastro-tourism development in Western Tourist Circuit, Kenya. Tourism and Hospitality Research, 12(4), 188-200. https://doi.org/10.1177/14673584 13491132
Ormanoviæ, Š., Æiriæ, A., Taloviæ, M., Aliæ, H., \& Jeleškoviæ, E. (2017). Importance-performance analysis: Different approaches. Acta Kinesiologica, 11(2), 58-66. Retrieved from http://actakinesiologica.com/wp-content/ uploads/2018/01/Ormanoviæ-2017.-Supp2-9. pdf

Pebriani, W. V., Sumarwan, U., \& Simanjuntak, M. (2018). The effect of lifestyle, perception, satisfaction, and preference on the online repurchase intention. Independent Journal of Management and Production, 9(2), 545-561. https://doi.org/10.14807/ijmp.v9i2.690

Pham, Q. T., Tran, X. P., Misra, S., Maskeliunas, R., \& Damaševièius, R. (2018). Relationship between convenience, perceived value, and repurchase intention in online shopping in Vietnam. Sustainability, 10(1), 1-14. https:// doi.org/10.3390/su10010156

Prastyaningsih, A. S., Suyadi, I., \& Yulianto, E. (2014). Pengaruh customer experience terhadap repurchase intention (survei pada konsumen KFC di lingkungan warga RW 3 Desa Kandangrejo, Kedungpring, Lamongan). Jurnal Administrasi Bisnis (JAB), 16(1), 18. Retrieved from http://administrasibisnis. studentjournal.ub.ac.id/index.php/jab/article/ download/669/868.

Rangkuti, F. (2003). Measuring customer satisfaction: Teknik mengukur dan strategi meningkatkan kepuasan pelanggan dan analisis kasus PLN-JP. Jakarta, Indonesia: Gramedia Pustaka Utama.

Rianto, R. K., Suharyono, \& Bafadhal, A. S. (2018). Pengaruh store environment terhadap shopping emotion dan impulse buying. Jurnal Administrasi Bisnis (JAB), 59(1), 8-15. Retrieved from http://administrasibisnis. studentjournal.ub.ac.id/index.php/jab/article/ viewFile/2449/2845

Rintamäki, T., Kanto, A., Kuusela, H., \& Spence, M. T. (2006). Decomposing the value of department store shopping into utilitarian, hedonic and social dimensions: Evidence from Finland. International Journal of Ritel \& Distribution Management, 34(1), 6-24. https:/ /doi.org/10.1108/09590550610642792

Saraswat, A., Mammen, T., Aagja, J. P., \& Tewari, R. (2010). Building store brands using store image differentiation. Journal of Indian 
Business Research, 2(3), 166-180. https:// doi.org/10.1108/MBE-09-2016-0047

Shabrina, Z., Yulianti, L. N., \& Simanjuntak, M. (2018). The effects of religiousity, pricing and corporate image on the attitude and the intention to use sharia micro financing. Indonesian Journal of Business and Entrepreneurship, 4(2), 196-205. https://doi.org/10.17358/ ijbe.4.2.197/

Shieh, J. I., \& Wu, H. H. (2009). Applying importance-performance analysis to compare the changes of a convenient store. Quality and Quantity, 43(3), 391-400. https://doi.org/ 10.1007/s11135-007-9111-5

Silva, F. de J., \& Fernandes, P. O. (2011). Importance-performance analysis as a tool in evaluating higher education service quality:The empirical results of ESTiG (IPB). In International Business Information Management Association Conference (pp. 306-315). Milan, Italy: International Business Information Management Association (IBIMA). Retrieved from https:// www.researchgate.net/publication/ 277035463_Importance-performance_ analysis_as_a_tool_in_evaluating_higher _education_service_quality_the_empirical_ results_of_ESTiG_IPB

Tripathi, S., \& Sinha, P. K. (2008). Choice of a ritel store and ritel store format: $A$ hierarchical logit model (No. 2008-4-3).
Indian Institution of Management Ahmedabad. Retrieved from https://web.iima.ac.in/assets/ snippets/working paperpdf/2008-04-03 Tripathi.pdf

Turley, L. W., \& Milliman, R. E. (2000). Atmospheric effects on shopping behavior: A review of the experimental evidence. Journal of Business Research, 49(2), 193-211. https:/ /doi.org/10.1016/S0148-2963(99)00010-7

United States Departement of Agriculture. (2017). Indonesia ritel foods update. Retrieved from https://gain.fas.usda.gov/Recent GAIN Publications/RitelFoods_Jakarta_ Indonesia_ 26-12-2017.pdf

Wong, M. S., Hideki, N., \& George, P. (2011). The use of importance-performance analysis (IPA) in evaluating Japan's e-government services. Journal of Theoretical and Applied Electronic Commerce Research, 6(2), 17-30. https://doi.org/ $10.4067 /$ S 0718 18762011000200003

Yüksel, A. (2007). Tourist shopping habitat: Effects on emotions, shopping value and behaviours. Journal of Tourism Management, 28(1), 5869. https://doi.org/10.1016/j.tourman.2005. 07.017

Yuniarinto, A., Thoyib, A., Solimun, \& Sularso, A. (2017). Ritel attribute's effect on shopping motivation and customer loyalty: Age as a moderating variable. Science Journal of Business and Management, 5(1), 27-36. https://doi.org/10.11648/j.sjbm.20170501.14 